Supporting Information for

\title{
Assembly pathway selection with DNA reaction circuits for programming multiple cell-cell signaling
}

Mingshu Xiao, ${ }^{1, \#}$ Wei Lai, ${ }^{1, \#}$ Huizhen Yu, ${ }^{1}$ Zijing Yu, ${ }^{1} \mathrm{Li} \mathrm{Li},{ }^{1}$ Chunhai Fan, ${ }^{2}$ and Hao $\operatorname{Pe}^{1, *}$

${ }^{1}$ Shanghai Key Laboratory of Green Chemistry and Chemical Processes, School of Chemistry and Molecular Engineering, East China Normal University, 500 Dongchuan Road, Shanghai, 200241, P. R. China

${ }^{2}$ School of Chemistry and Chemical Engineering, and Institute of Molecular Medicine, Renji Hospital, School of Medicine, Shanghai Jiao Tong University, Shanghai 200240, China

*Corresponding author. Email: peihao@chem.ecnu.edu.cn 


\section{Experimental Section}

\section{Reagents and materials.}

All DNA oligonucleotides listed in Table S1 were designed with NUPACK to minimize undesired secondary structures and provided by Sangon Biotech Co., Ltd. (Shanghai, China). The DNA concentration was quantified by the measurement of the absorbance at $260 \mathrm{~nm}$ (Agilent cary60 UV-Vis spectrophotometer, Agilent, American). Propidium Iodide and Calcein-AM were purchased from Thermo Fisher Scientific Inc. (Waltham, MA, USA). Hoechst 33342 were obtained from Sangon Biotech Co., Ltd. (Shanghai, China).

DNA oligonucleotides were dispersed $1 \times \mathrm{TE} / \mathrm{Mg}^{2+}$ buffer $(10 \mathrm{mM}$ Tris, $1 \mathrm{mM}$ EDTA $\cdot \mathrm{Na} 2,12.5 \mathrm{mM} \mathrm{Mg}^{2+}, \mathrm{pH}=8$ ) and stored at $4{ }^{\circ} \mathrm{C}$ for further use. All experiments were performed at room temperature.

Cell culture conditions. All cells used in this work, including NK, K562, and Jurkat cells were supplied by ATCC. K562 and Jurkat cells were cultured in RPMI-1640 supplemented with $10 \%$ FBS and $0.5 \mathrm{mg} / \mathrm{mL}$ penicillin-streptomycin (Cellgro). NK cells were maintained in Alpha Minimum Essential Medium supplemented with 0.2 $\mathrm{mM}$ inositol, $0.1 \mathrm{mM}$ 2-mercaptoethanol, $0.02 \mathrm{mM}$ folic acid, 12.5\% horse serum and $12.5 \%$ FBS. Cells were cultured at $37^{\circ} \mathrm{C}$ in humidified environment containing $5 \% \mathrm{CO}_{2}$.

Agarose gel electrophoresis (AGE). To verify the formation of 3-arm DNA structures, $10 \mu \mathrm{L}$ of $1 \mu \mathrm{M}$ DNA sample was mixed with $2 \mu \mathrm{L}$ of $6 \times$ loading buffer. $2 \%$ AGE was carried out in $1 \times \mathrm{LB}$ buffer $\left(10 \mathrm{mM} \mathrm{LiOH} \cdot \mathrm{H}_{2} \mathrm{O}, 29.1 \mathrm{mM} \mathrm{H}_{3} \mathrm{BO}_{3}\right)$ at $100 \mathrm{~V}$ for $60 \mathrm{~min}$. Following, the AGE was stained with Gel-Red (Solarbio) for 20 min and visualized on a UV transilluminator of the UVP GelDoc-It 310 Imaging System under an excitation wavelength of $365 \mathrm{~nm}$.

Fluorescence kinetics measurement. Fluorescence kinetics measurement was performed with a Hitachi F-7000 fluorometer for monitoring the rational designed DNA circuits with pathway selection for molecular assembly. The excitation/emission 
wavelengths were set at 494/518 $\mathrm{nm}$ for 6-FAM and 649/670 $\mathrm{nm}$ for Cy5, respectively. All circuit units (each unit with final concentration of $10 \mathrm{nM}$ ) were mixed in $1 \mathrm{~mL}$ of $1 \times \mathrm{TE} / \mathrm{Mg}^{2+}$ buffer. After addition of $15 \mathrm{nM}$ of activators (Act-B or Act-C) and A (or D), the changed fluorescence was recorded. Finally, the fluorescence spectra were normalized (a.u.).

Allosteric activation for molecular assembly of DNA duplex. For assembly of DNA duplex with DNA circuit, circuit units including initiator (I), $\mathrm{A}_{\mathrm{OFF}}$ and B were dispersed in $200 \mu \mathrm{L} 1 \times \mathrm{TE} / \mathrm{Mg}^{2+}$ buffer with a final concentration of $10 \mathrm{nM}$, followed by addition of Act-A with final concentration of $15 \mathrm{nM}$. The assembled DNA duplex was characterized by AGE and fluorescence spectra.

DNA circuits with APS for molecular assembly. For assembly of 3-arm DNA structures with Circuit 1, circuit units including initiator (I), A, $\mathrm{B}_{\mathrm{OFF}}, \mathrm{C}_{\mathrm{OFF}}$, and D were dispersed in $200 \mu \mathrm{L} 1 \times \mathrm{TE} / \mathrm{Mg}^{2+}$ buffer with a final concentration of $10 \mathrm{nM}$. After adding Act-B or Act-C (a final concentration of $15 \mathrm{nM}$ ), the formed three-way DNA structures were characterized by AGE. In circuit 2, circuit units including initiator (I), $\mathrm{A}_{\mathrm{OFF}}, \mathrm{B}_{\mathrm{OFF}}$ and $\mathrm{C}_{\mathrm{OFF}}$ were dispersed in $200 \mu \mathrm{L} 1 \times \mathrm{TE} / \mathrm{Mg}^{2+}$ buffer with a final concentration of $10 \mathrm{nM}$. After successive addition of Act-A, Act-B and Act-C (final concentration of $15 \mathrm{nM}$ ), the mixture was monitored with fluorescence spectra and the obtained three-way DNA structures were characterized by AGE. Similarily, $\mathrm{C}_{\mathrm{OFF}}, \mathrm{B}_{\mathrm{OFF}}$, $\mathrm{C}_{\mathrm{ON}} \cdot \mathrm{D}$ and $\mathrm{A} \cdot \mathrm{B}_{\mathrm{ON}}$ were dispersed in $200 \mu \mathrm{L} 1 \times \mathrm{TE} / \mathrm{Mg}^{2+}$ buffer with a final concentration of $10 \mathrm{nM}$ for circuit 3, and characterized with fluorescence spectra after adding Act-B or Act-C (final concentration of $15 \mathrm{nM}$ ).

DNA circuit networks with APS for molecular assembly on cell-surface. To construct DNA circuit networks on membrane, $6 \mu \mathrm{M}$ of the designed circuit units (i.e., $B$ and C) was used for engineering NK cell surface $\left(1 \times 10^{6} / \mathrm{mL}\right)$ for $30 \mathrm{~min}$. Then, free DNA circuit units were removed by centrifugation, and the engineered cells were resuspended in $100 \mu \mathrm{L}$ Alpha Minimum Essential Medium. In subsequent, circuit units A, D and initiator (I) with a final concentration of $4 \mu \mathrm{M}$ were added into medium. 
Finally, after adding $10 \mu \mathrm{M}$ activator (Act-B or Act-C) and shaking mixture at $300 \mathrm{rpm}$ for $30 \mathrm{~min}$, the molecular assembly on cell-surface were characterized with fluorescence imaging and flow cytometry analysis.

\section{DNA circuit networks with APS for programmable regulation of cell-cell}

interactions. The NK cells, Jurkat cells, and K562 cells were modified with circuit units $\left(\mathrm{A}_{\mathrm{OFF}}\right.$ and $\left.\mathrm{B}_{\mathrm{OFF}}\right)$, Cy5-labelled $\mathrm{C}$, and FAM-labelled $\mathrm{E}$, respectively. Then, the engineered K562 (or Jurkat, $1 \times 10^{6} / \mathrm{mL}$ ) and NK cells $\left(1 \times 10^{5} / \mathrm{mL}\right)$ were mixed into 100 $\mu \mathrm{L}$ cell culture medium with a ratio of $10: 1$, followed by addition of other circuit units (including $\mathrm{D}$ and $\mathrm{F}$ ) and initiators $\left(\mathrm{I}_{1}\right.$ and $\left.\mathrm{I}_{2}\right)$ into the mixture. For programmable regulation of NK cell-Jurkat cell or NK cell-K562 cell interactions, Act-A or Act-B were added to activate the DNA circuit networks. After shaking at $300 \mathrm{rpm}$ for $30 \mathrm{~min}$ under room temperature, the $1 \times 10^{4}$ cells were collected for observation with CLSM (Leica TCS SP8 Confocal microscope, Germany) or analyzed by flow cytometry (an ImageStream mkII system, Merk Serono Co., Ltd., Darmstadt, Germany). The assembly efficiency of NK cells to Jurkat cells (or K562 cells) was calculated with the ratio of amounts of assembled NK cells to amounts of total NK cells.

Cell killing assays. The engineered K562 $\left(1 \times 10^{6} / \mathrm{mL}\right)$, Jurkat $\left(1 \times 10^{6} / \mathrm{mL}\right)$, and NK cells $\left(1 \times 10^{5} / \mathrm{mL}\right)$ were mixed into $200 \mu \mathrm{L}$ cell culture medium with a ratio of 10:10:1. Then, circuit units (D and F) and initiators $\left(\mathrm{I}_{1}\right.$ and $\left.\mathrm{I}_{2}\right)$ were added into the cell mixture, followed by addition of Act-A and Act-B (or Act-A, Act-B). Cell mixtures were gently shaken at $300 \mathrm{rpm}$ for $30 \mathrm{~min}$ to avoid nonspecific cell binding, then incubated in a humidified atmosphere with $5 \% \mathrm{CO}_{2}$ at $37{ }^{\circ} \mathrm{C}$ for $4 \mathrm{~h}$. Finally, cell mixtures were prestained with green fluorescence Calcein-AM and red fluorescence PI and observed by CLSM. The resulting apoptosis/death rates were calculated with the ratio of amounts of apoptotic cells to amounts of total cells. Each same experiment was repeated for 3 times and $2 \times 10^{3}$ cells were collected for analysis at each time. 
a

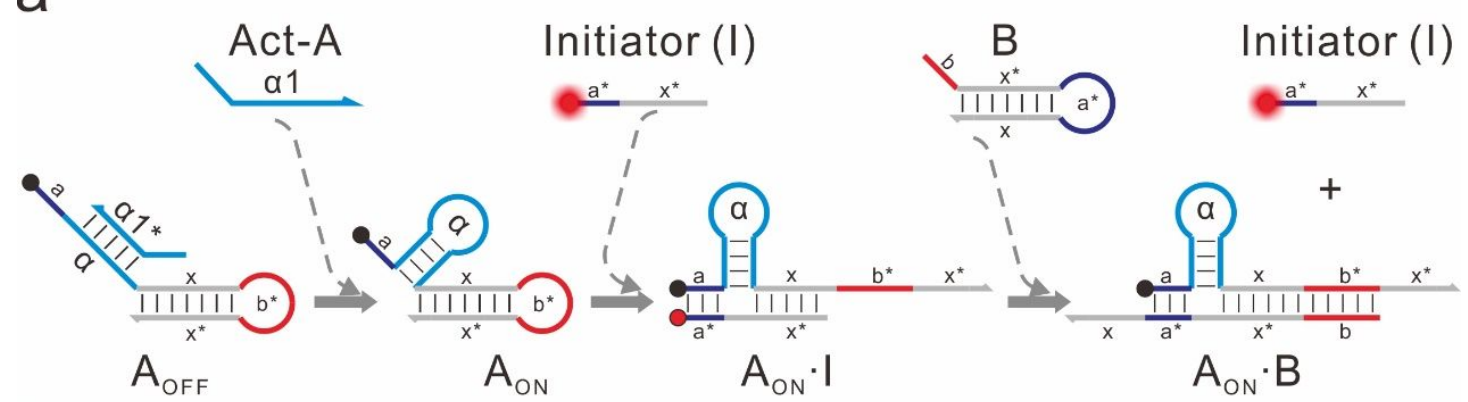

b

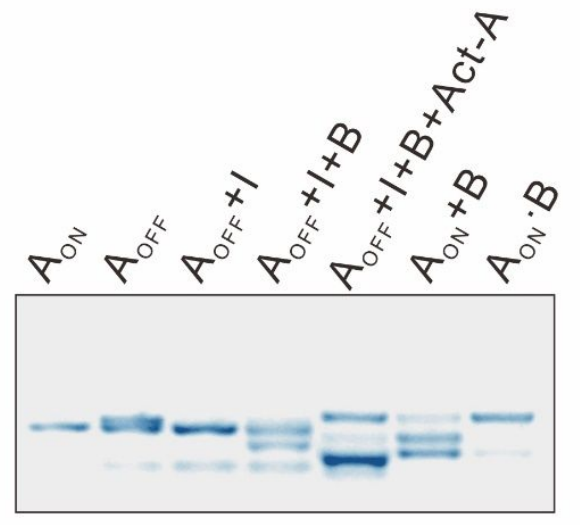

C

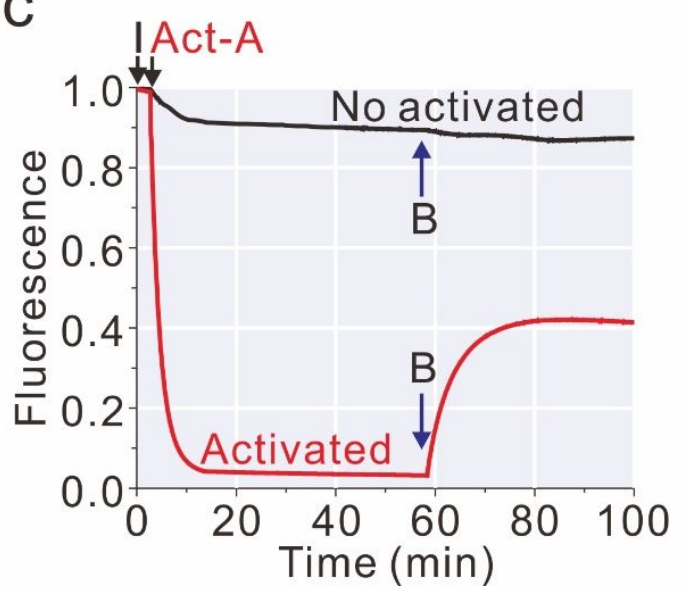

Figure S1. (a) Scheme of Act-A-activated molecular assembly of DNA duplex. Characterization of molecular assembly of DNA duplex by (b) AGE analysis and (c) fluorescence spectra $\left(\left[\mathrm{A}_{\mathrm{OFF}}\right]=10 \mathrm{nM},[\mathrm{I}]=10 \mathrm{nM},[\mathrm{B}]=10 \mathrm{nM}\right.$ and $[$ Act-A $\left.]=15 \mathrm{nM}\right)$. 


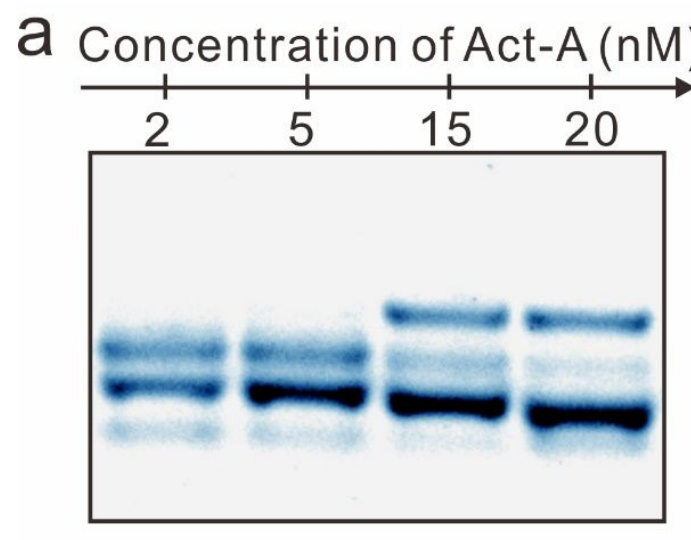

C

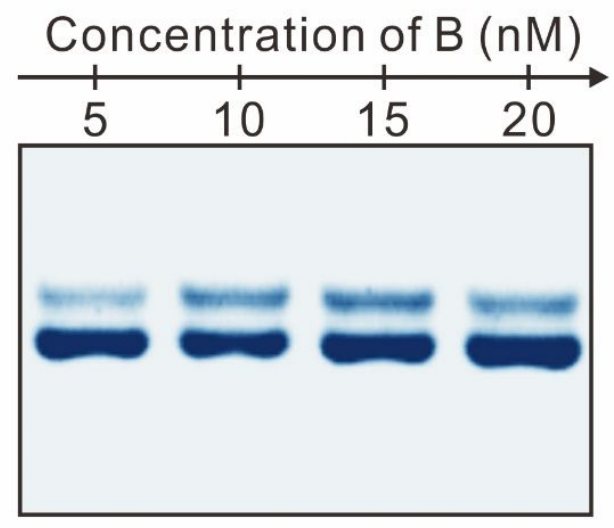

$b$

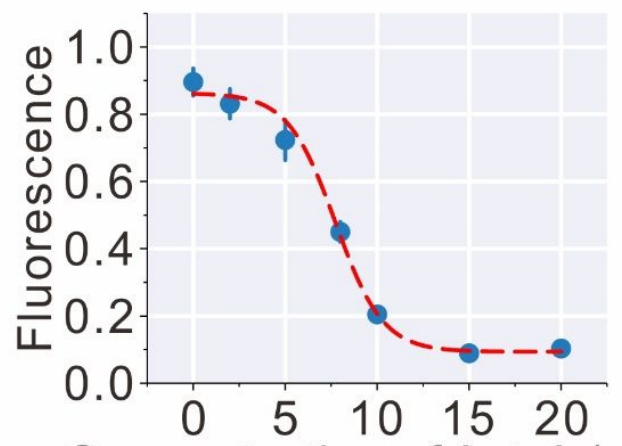

O

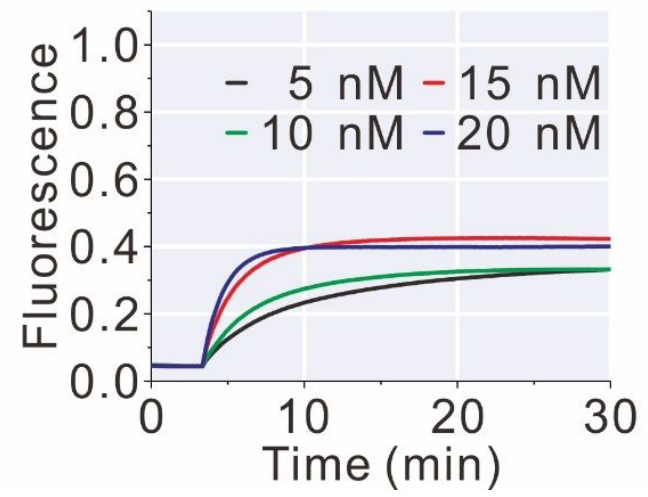

Figure S2. (a) AGE analysis and (b) fluorescence signal of molecular assembly of DNA duplex by changing the concentration of Act-A from 0 to $20 \mathrm{nM}\left(\left[\mathrm{A}_{\mathrm{OFF}}\right]=10 \mathrm{nM},[\mathrm{I}]\right.$ $=10 \mathrm{nM}$ ). (c) AGE analysis and (d) fluorescence spectra of molecular assembly of DNA duplex by changing the concentration of $\mathrm{B}$ from 5 to $20 \mathrm{nM}\left(\left[\mathrm{A}_{\mathrm{OFF}}\right]=10 \mathrm{nM},[\mathrm{I}]\right.$ $=10 \mathrm{nM},[$ Act-A] $=15 \mathrm{nM}$.). 
a

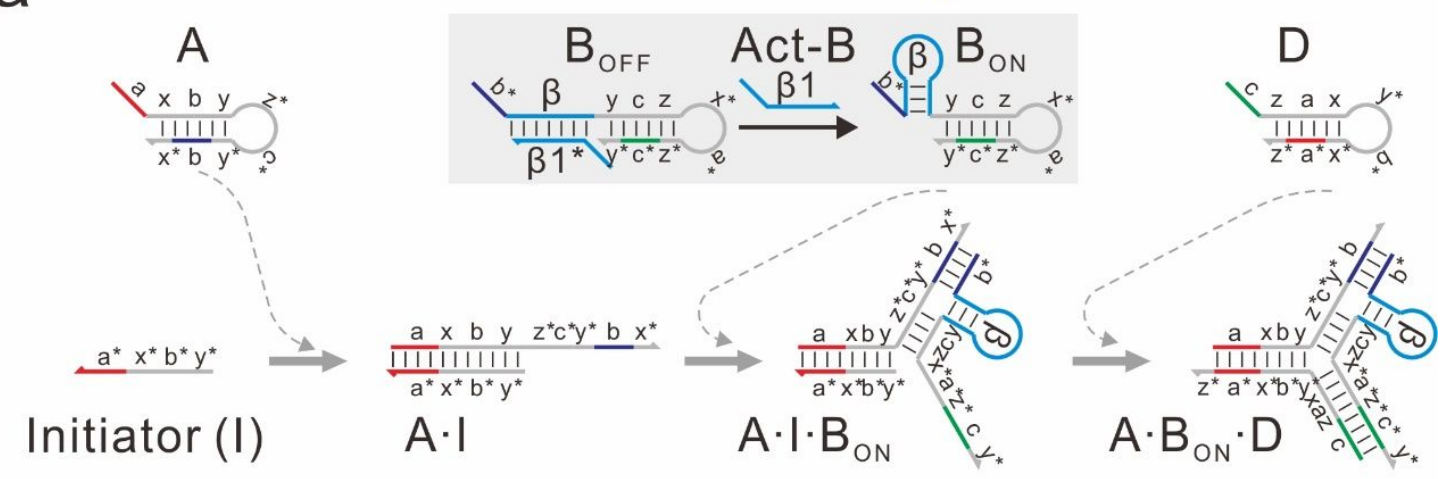

b

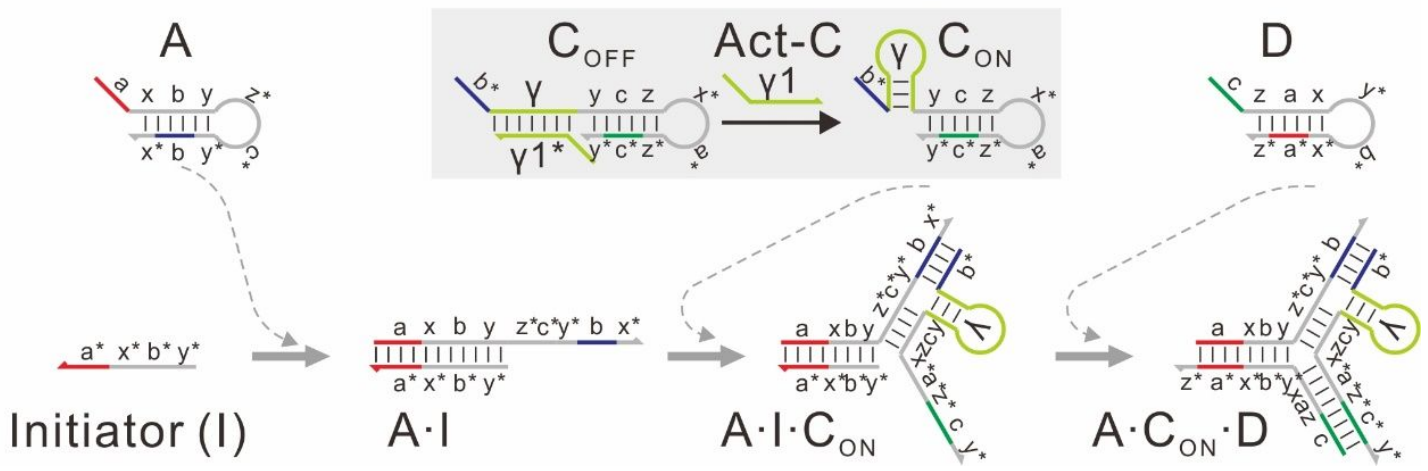

Figure S3. (a) Scheme of Act-B-activated Circuit 1 for molecular assembly of threeway junction DNA structures in Pathway I. (b) Scheme of Act-C-activated Circuit 1 for molecular assembly of three-way junction DNA structures in Pathway II.

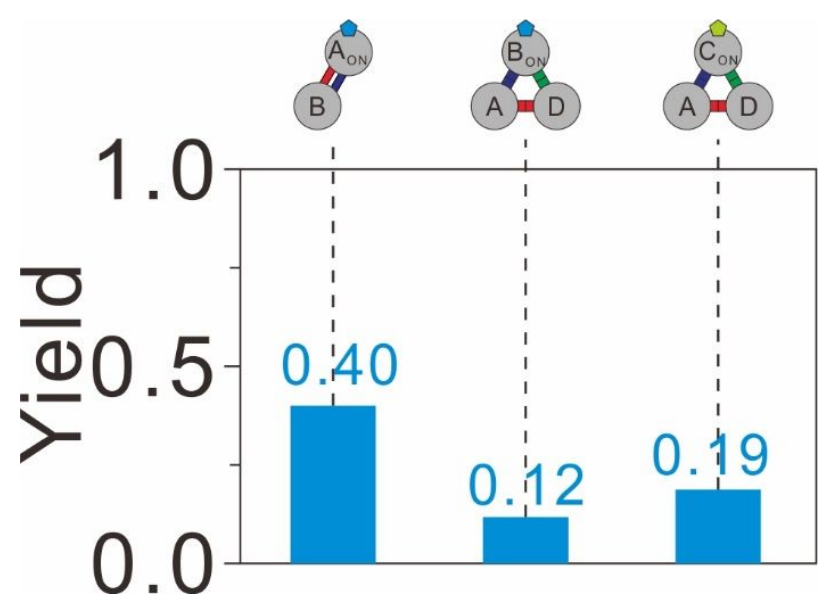

Figure S4. The yield of $\mathrm{A}_{\mathrm{ON}}-\mathrm{B}, \mathrm{A} \cdot \mathrm{B}_{\mathrm{ON}} \cdot \mathrm{D}$ and $\mathrm{A} \cdot \mathrm{C}_{\mathrm{ON}} \cdot \mathrm{D}$. 


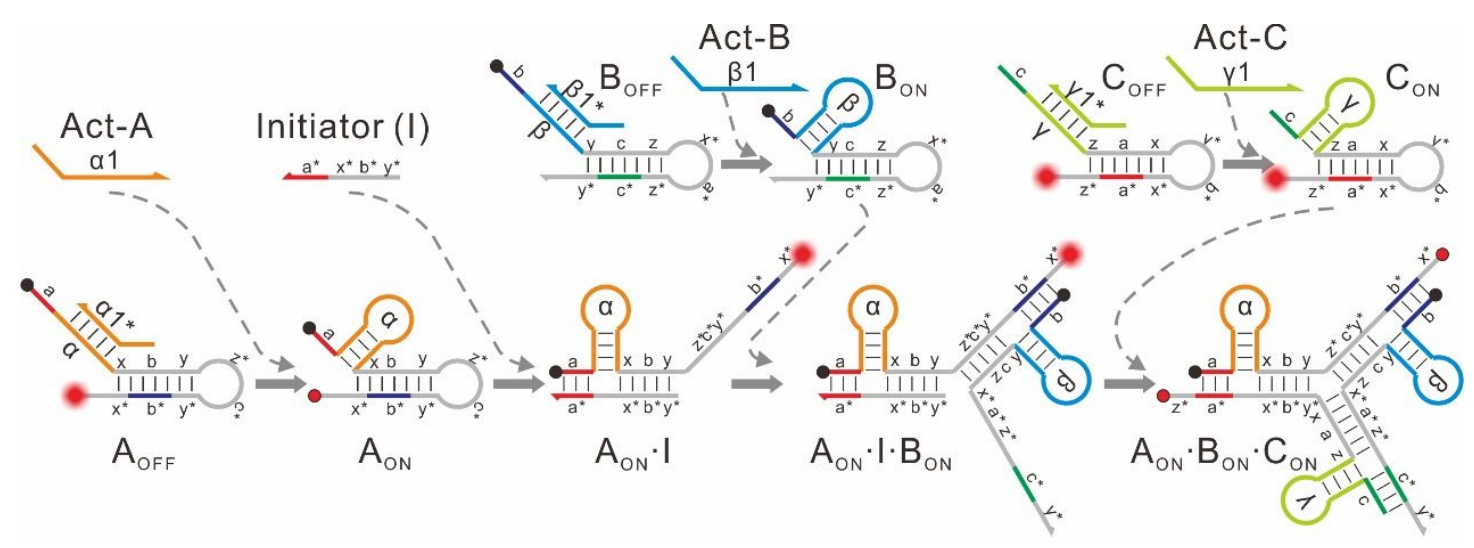

Figure S5. Scheme of Act-A, Act-B and Act-C-activated Circuit 2 for molecular assembly of three-way junction DNA structures with three stem-loops.

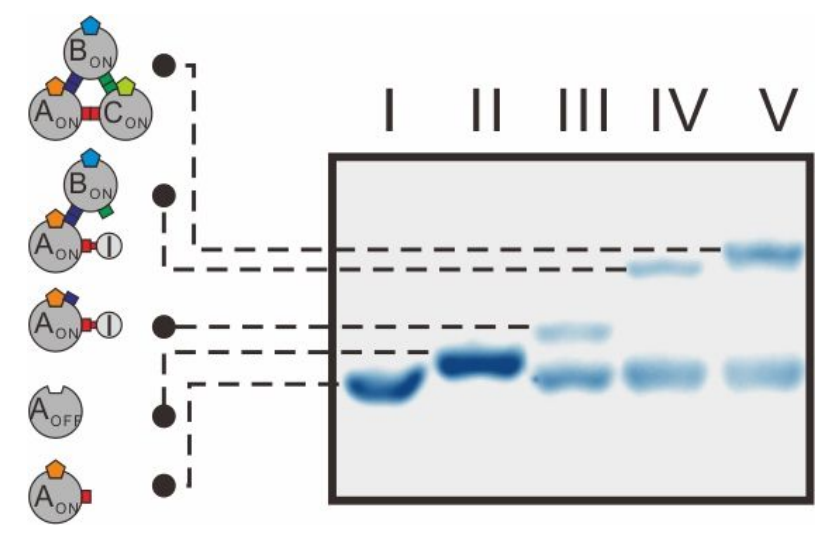

Figure S6. AGE analysis of DNA circuits for molecular assembly by allosteric activation. Lane I ( $\mathrm{A}_{\mathrm{OFF}}, \mathrm{B}_{\mathrm{OFF}}$ and $\left.\mathrm{C}_{\mathrm{OFF}}\right)$, lane II ( $\mathrm{A}_{\mathrm{ON}}, \mathrm{B}_{\mathrm{ON}}$ and $\left.\mathrm{C}_{\mathrm{ON}}\right)$, lane III (I, $\mathrm{A}_{\mathrm{OFF}}$, $\mathrm{B}_{\mathrm{OFF}}, \mathrm{C}_{\mathrm{OFF}}$ and Act-A), lane IV (I, $\mathrm{A}_{\mathrm{OFF}}, \mathrm{B}_{\mathrm{OFF}}, \mathrm{C}_{\mathrm{OFF}}$, Act-A and Act-B), lane V (I, $\mathrm{A}_{\mathrm{OFF}}$, $\mathrm{B}_{\mathrm{OFF}}, \mathrm{C}_{\mathrm{OFF}}$, Act-A, Act-B and Act-C). 


\section{Circuit 3: Pathway I}

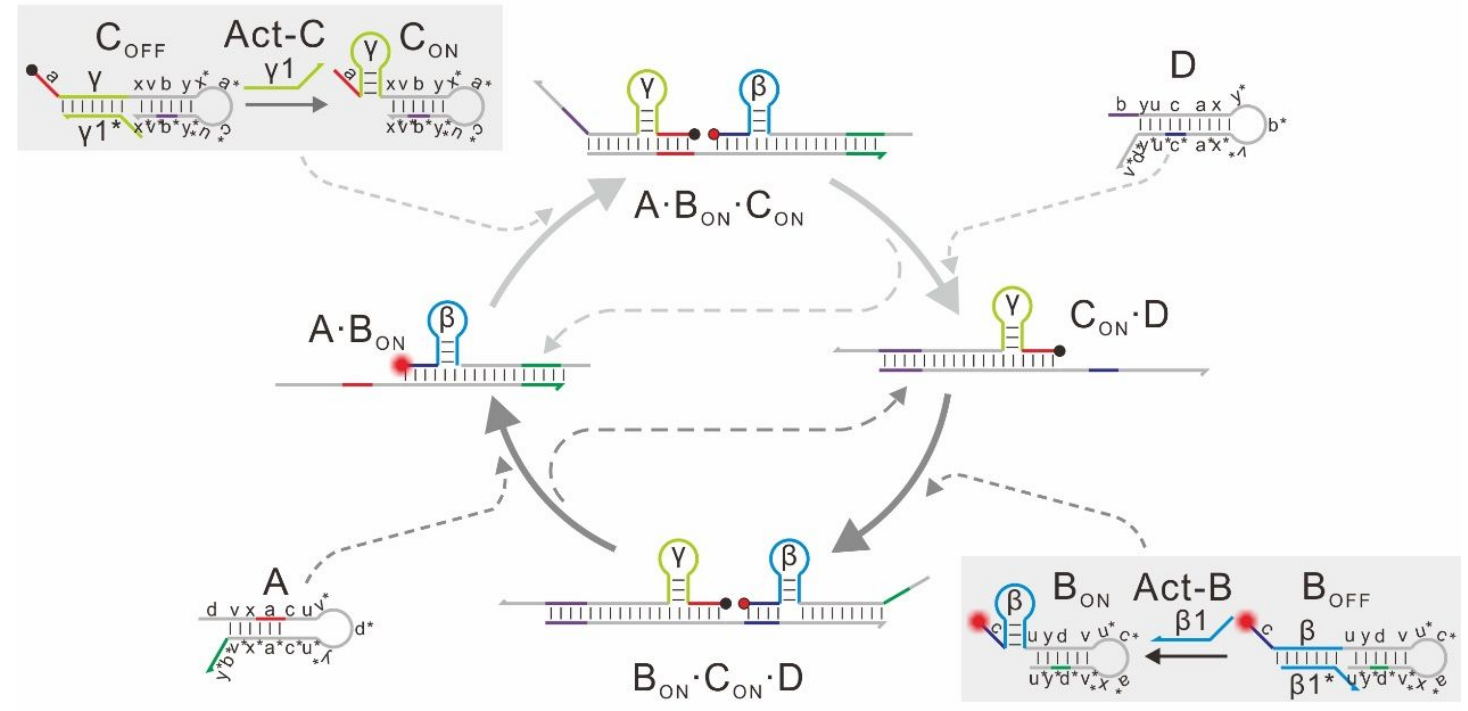

Circuit 3: Pathway II

Figure S7. Scheme of Act-C-activated Circuit 2 and Act-B-activated Circuit 2 for molecular assembly of duplex DNA structures in Pathway I and in Pathway II, respectively.

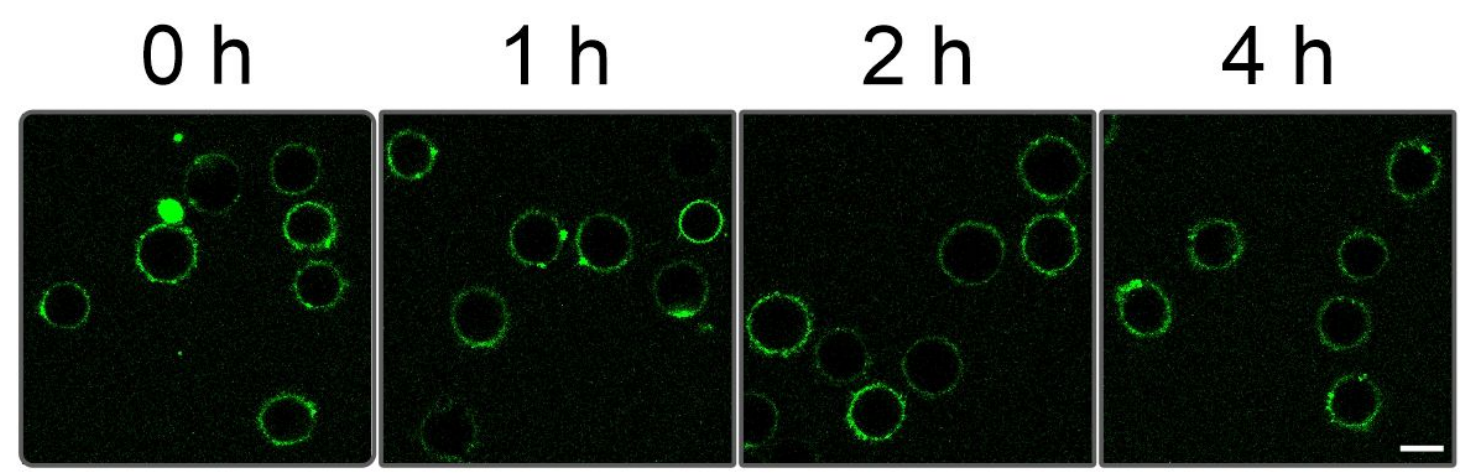

Figure S8. Stability study of cell surface-attached FAM-labelled DNA circuits in $4 \mathrm{~h}$. Scale bar: $10 \mu \mathrm{m}$. 


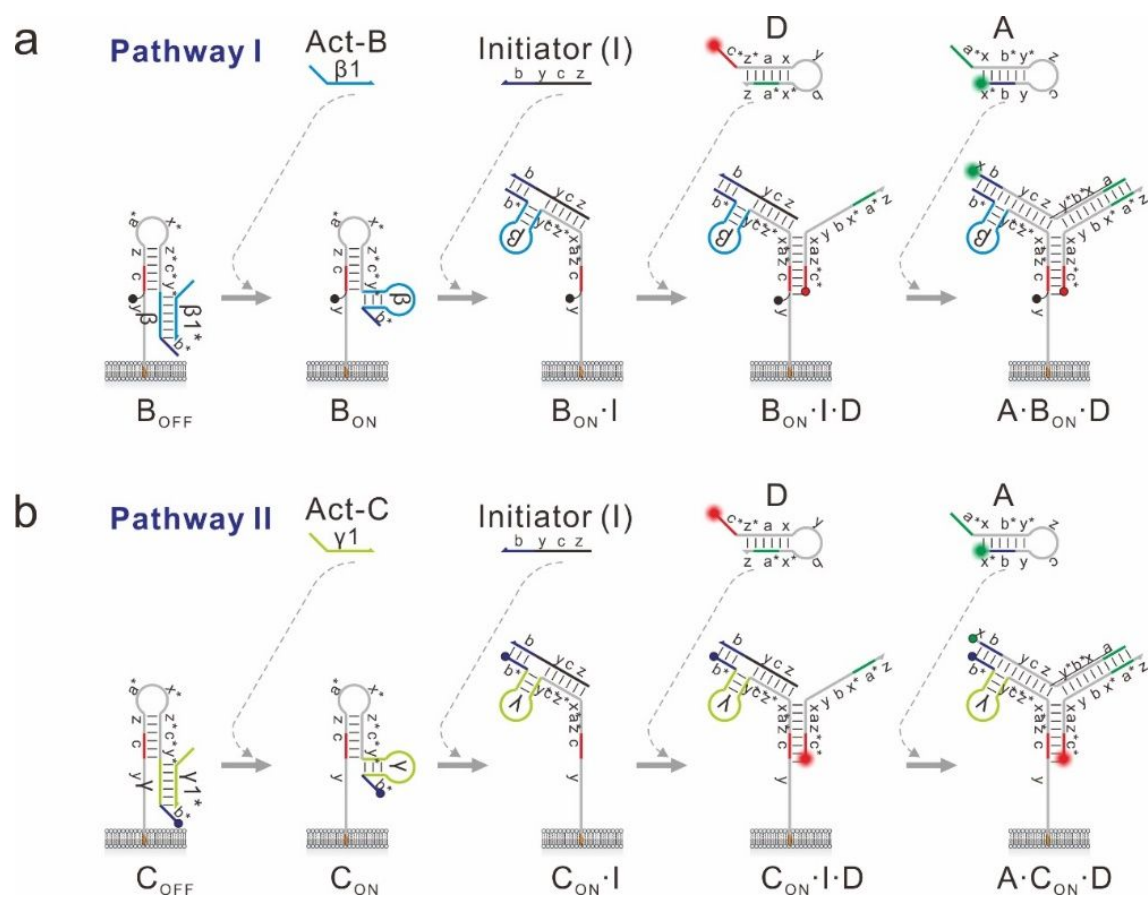

Figure S9. (a) Scheme of molecular assembly of three-way junction DNA structures in Pathway I on membrane after allosteric activation by Act-B. (b) Scheme of molecular assembly of three-way junction DNA structures in Pathway II on membrane after allosteric activation by Act-C.

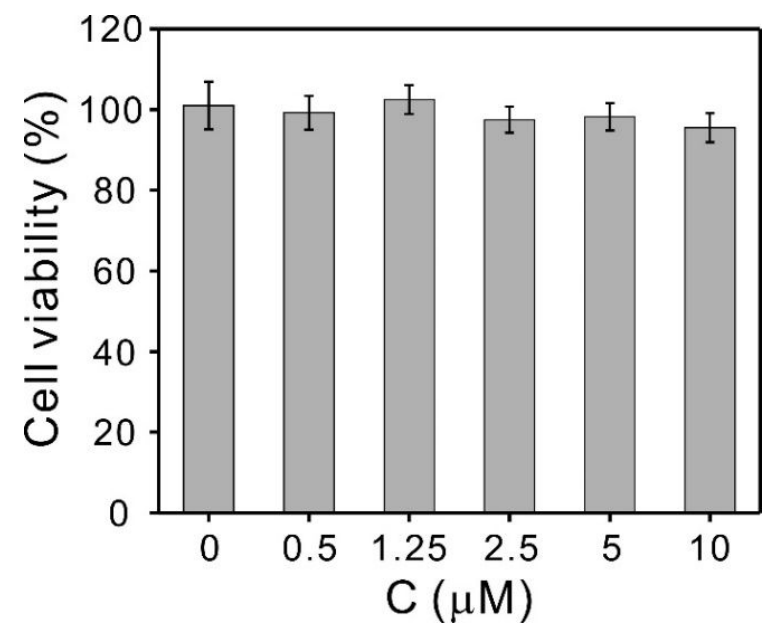

Figure S10. The Cytotoxicity of different concentration of DNA circuit units to NK cells after incubation for $24 \mathrm{~h}$. Error bars represent the standard deviation of three independent experiments. 

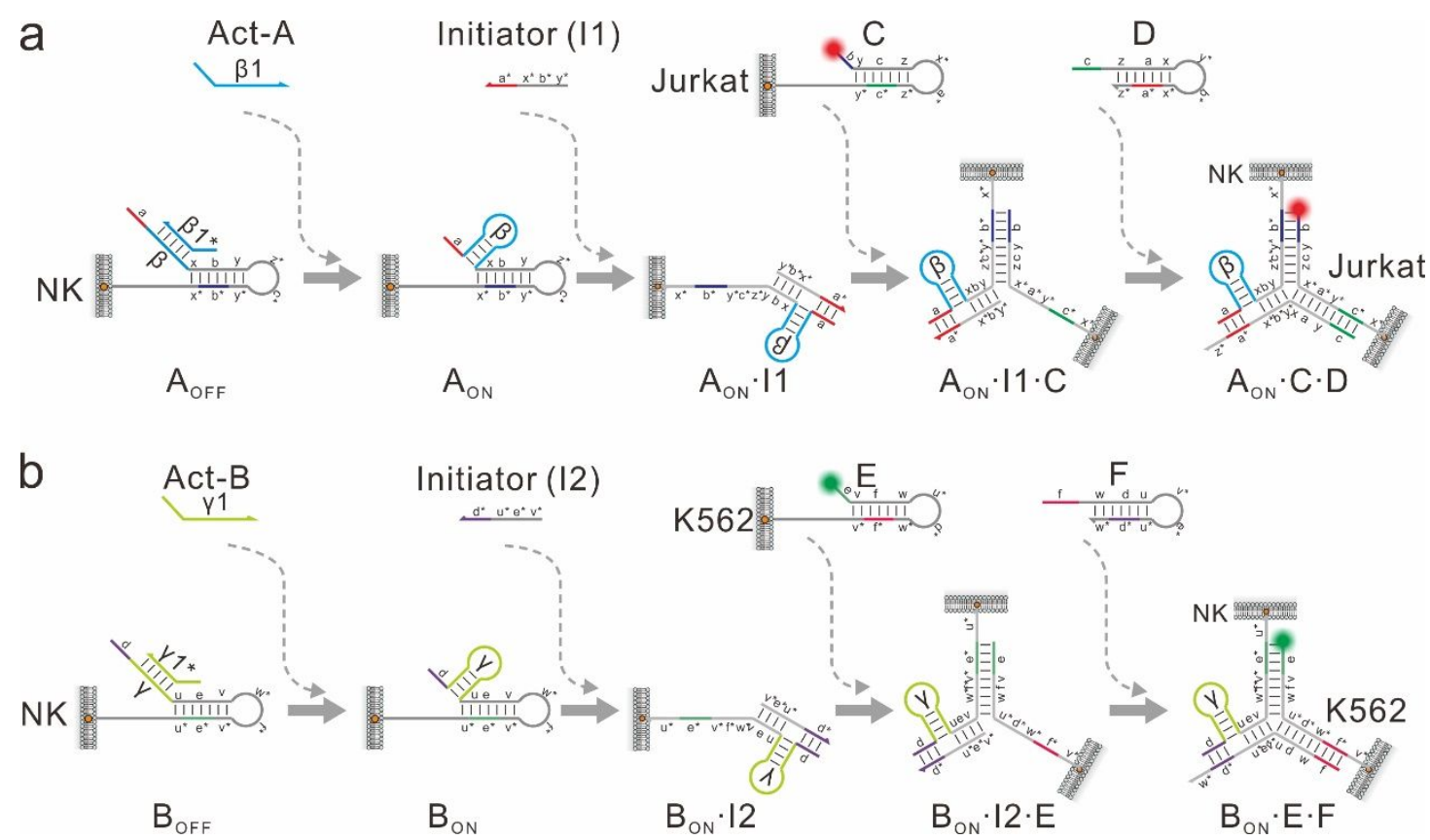

Figure S11. (a) Scheme of assembly of three-way junction DNA structures for connections between NK cell-Jurkat cell in the presence of Act-A. (b) Scheme of assembly of three-way junction DNA structures for connections between NK cell-K562 cell in the presence of Act-B.
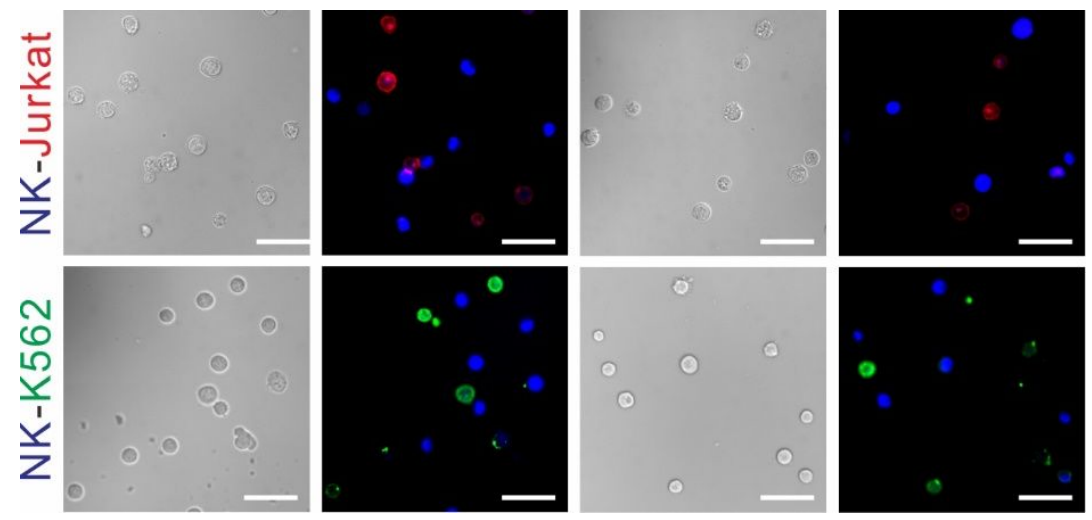

Figure S12. CLSM images of assembly of NK cell-Jurkat cell (upper) and NK cellK562 cell (lower) in the presence of mock-activators (left) and without activator (right). Jurkat cell and K562 cell were labelled by Cy5 and FAM, respectively. The nuclei of NK cells were stained by Hoechst 33342. Scale bar: $50 \mu \mathrm{m}$. 


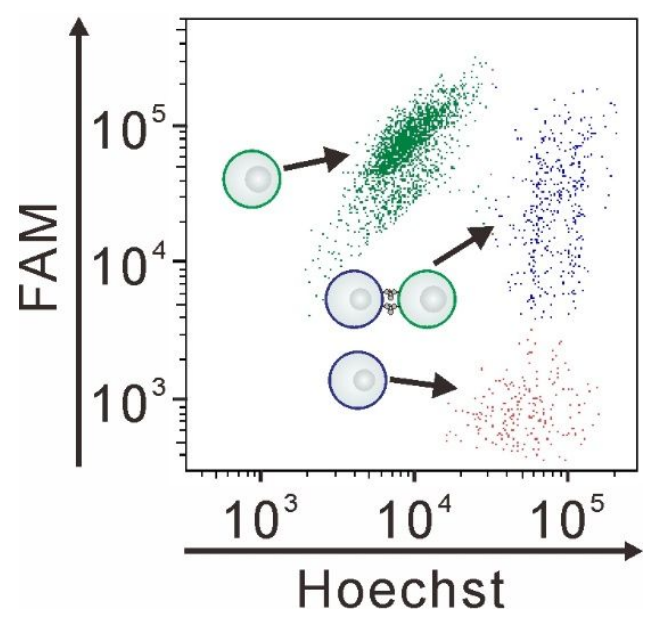

Figure S13. Flow cytometry analysis of assembly of NK cell-K562 cell with DNA circuit networks in the presence of Act-B.
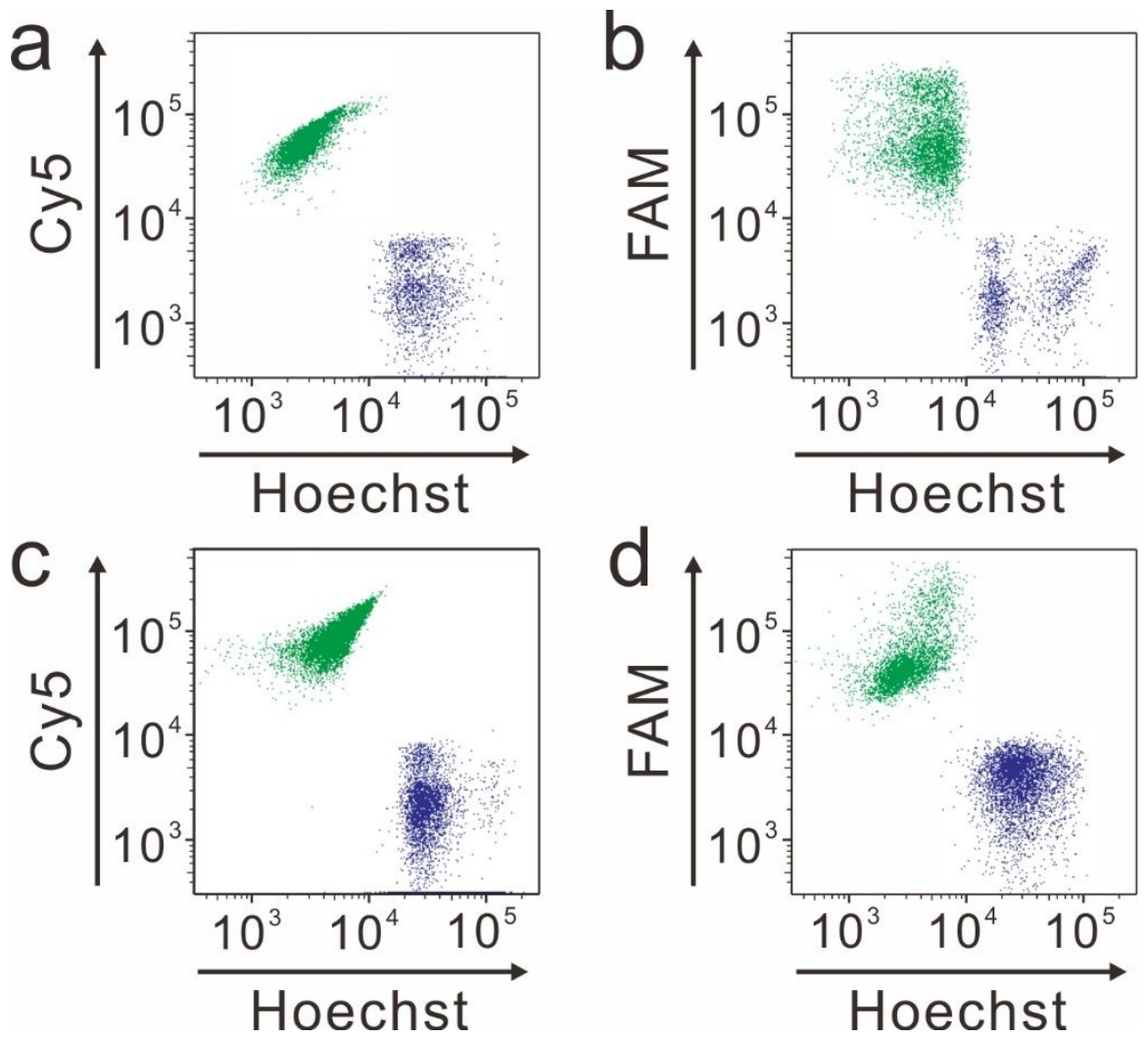

Figure S14. Flow cytometry analysis of assembly of (a and c) NK cell-Jurkat cell and (b and d) NK cell-K562 cell with DNA circuit networks (a and b) without activator or (c and d) in the presence of mock-activators. 


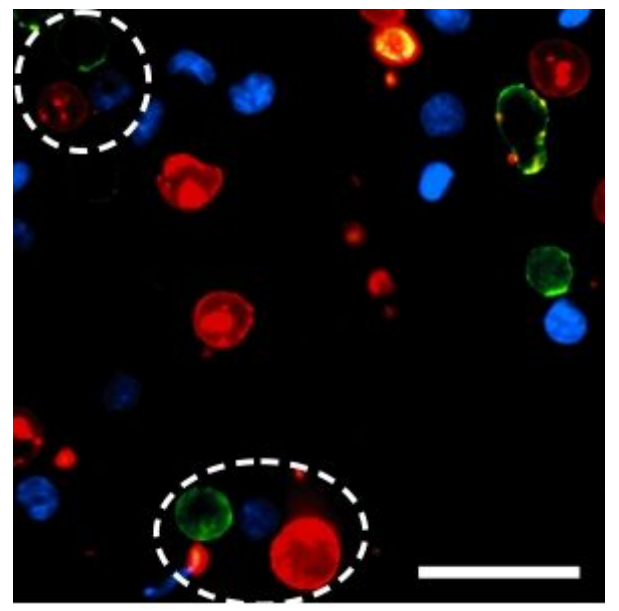

Figure S15. CLSM images of the assembly of three types of cells in the presence of both Act-A and Act-B. Jurkat cell and K562 cell were labelled by Cy5 and FAM, respectively. The nuclei of NK cells were stained by Hoechst 33342. Circle indicates assembly of three types of cells. Scale bar: $50 \mu \mathrm{m}$.
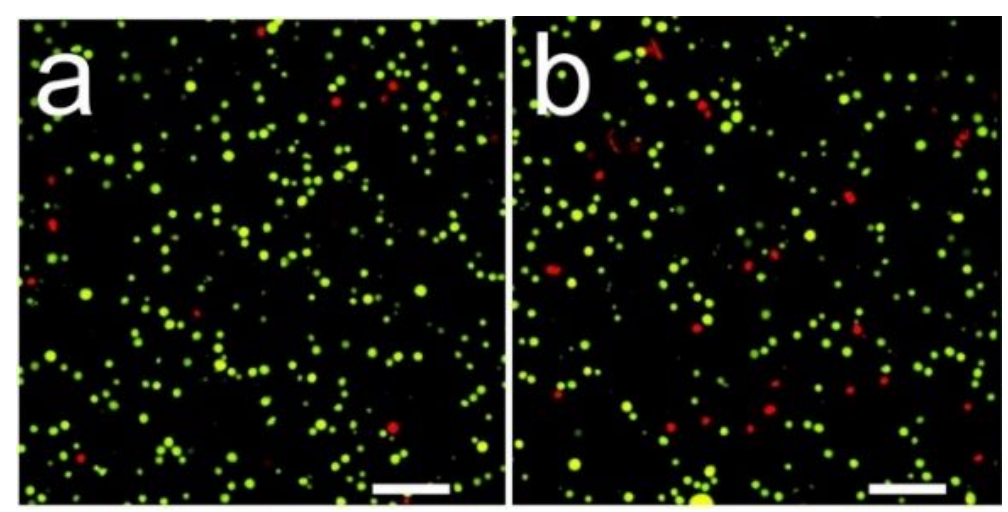

Figure S16. Fluorescence images of calcein AM (green, live cells) and PI (red, dead cells) co-stained (a) non-target cells without engineered with DNA circuit networks and (b) cells engineered with DNA circuit networks in the presence of mock-activators. Scale bar: $100 \mu \mathrm{m}$.

Table S1. The DNA used in this work

\begin{tabular}{|l|c|lc|}
\hline & Name & \multicolumn{2}{c|}{ The sequence of DNA (5' to 3') } \\
\hline Assembly of & A & BHQ1- & \\
\hline
\end{tabular}




\begin{tabular}{|c|c|c|}
\hline \multirow[t]{5}{*}{$\begin{array}{l}\text { duplex } \\
\text { system }\end{array}$} & & $\begin{array}{l}\text { GTAAGTAGTGCACGCCTTATTATTATCTCTTGGCGTGCGAT } \\
\text { TGAGCGTGATGAATGTCACTACTTACCAACTCGCATTCATC } \\
\text { ACGCTCAATC }\end{array}$ \\
\hline & B & $\begin{array}{l}\text { TGATGAATGCGAGTTGGTAAGTAGTGACATTCATCACGCT } \\
\text { CAATCACTACTTACCAACTCGCA }\end{array}$ \\
\hline & I & GACATTCATCACGCTCAATCTTACTACTTAC-6-FAM \\
\hline & Rep-A & TAGGAGTCGCCAAGAGATAATAATAAGGCG \\
\hline & Act-A & CGCCTTATTATTATCTCTTGGCGACTCCTA \\
\hline \multirow{9}{*}{$\begin{array}{l}\text { Assembly of } \\
\text { 3-arm DNA } \\
\text { structures }\end{array}$} & A & $\begin{array}{l}\text { GTCTGTGATGATGTTAGGGAGAGTTAGTGCTCCAATACTCACAACGC } \\
\text { АCTAАСТСТСССТААСTT }\end{array}$ \\
\hline & B & $\begin{array}{l}\text { AGGGAGAGTCGTGCGGTTCTCTATTATTATTCCGCACGTAGTGCGTT } \\
\text { GTGAGTATTGGAAACATCATCACAGACTCCAATACTCACAACGC }\end{array}$ \\
\hline & $\mathrm{C}$ & $\begin{array}{l}\text { AGGGAGAGTGCCATGCTCACTCTACTACACAGCATGGCTAGTGCGTT } \\
\text { GTGAGTATTGGAAACATCATCACAGACTCCAATACTCACAAC }\end{array}$ \\
\hline & $\mathrm{D}$ & $\begin{array}{l}\text { GTTGTGAGTATTGGAGTCTGTGATGATGTTGCACTAACTCTCCCTAAC } \\
\text { ATCATCACAGAC }\end{array}$ \\
\hline & I & GCACTAACTCTCCCTAACATCATCACAGAC \\
\hline & Rep-B & GCGGAATAATAATAGAGAACCGCTAGGACT \\
\hline & Rep-C & GACCTAGATGCTGTGTAGTAGAGTGAGCAT \\
\hline & Act-B & AGTCCTAGCGGTTCTCTATTATTATTCCGC \\
\hline & Act-C & ATGCTCACTCTACTACACAGCATCTAGGTC \\
\hline \multirow{9}{*}{$\begin{array}{c}\text { Assembly of } \\
\text { 3-arm DNA } \\
\text { structures } \\
\text { with 3- } \\
\text { allosteric } \\
\text { switches }\end{array}$} & A & $\begin{array}{l}\text { BHQ1- } \\
\text { GTCTGTGATGCACGCCTTATTATTATCTCTTGGCGTGCGATGTTAGGG } \\
\text { AGAGTTAGTGCTCCAATACTCACAACGCACTAACTCTCCCTAACTT-6- } \\
\text { FAM }\end{array}$ \\
\hline & B & $\begin{array}{l}\text { BHQ1- } \\
\text { AGGGAGAGTCGTGCGGTTCTCTATTATTATTCCGCACGTAGTGCGTT } \\
\text { GTGAGTATTGGAAACATCATCACAGACTCCAATACTCACAACGC }\end{array}$ \\
\hline & $\mathrm{C}$ & $\begin{array}{l}\text { GTTGTGAGTGCCATGCTCACTCTACTACACA GCATGGCATTGGAGTC } \\
\text { TGTGATGATGTTGCACTAACTCTCCCTAACATCATCACAGACTC-6- } \\
\text { FAM }\end{array}$ \\
\hline & I & GCACTAACTCTCCCTAACATCTTATCACAGAC \\
\hline & Rep-A & TAGGAGTCGCCAAGAGATAATAATAAGGCG \\
\hline & Rep-B & GCGGAATAATAATAGAGAACCGCTAGGACT \\
\hline & Rep-C & GACCTAGATGCTGTGTAGTAGAGTGAGCAT \\
\hline & Act-A & CGCCTTATTATTATCTCTTGGCGACTCCTA \\
\hline & Act-B & AGTCCTAGCGGTTCTCTATTATTATTCCGC \\
\hline
\end{tabular}




\begin{tabular}{|c|c|c|}
\hline & Act-C & ATGCTCACTCTACTACACAGCATCTAGGTC \\
\hline \multirow{8}{*}{$\begin{array}{l}\text { Assembly of } \\
\text { DNA } \\
\text { duplexes }\end{array}$} & A & $\begin{array}{l}\text { ACAACTGCTCTACCACTTCTCAATCCCTATCTCCATTACAACTCGACA } \\
\text { CCCACTTGGAGATAGGGATTGAGAAGTGGGTGTCGA }\end{array}$ \\
\hline & $\mathrm{B}$ & $\begin{array}{l}\text { ACTCGACACCCACTTCTCAATCCCTATCTCCAAGTGGGTGTCGAGTT } \\
\text { GTCGTGCGGTTCTCTATTATTATTCCGCACGTGGAGATAG-6-FAM }\end{array}$ \\
\hline & $\mathrm{C}$ & $\begin{array}{l}\text { BHQ1- } \\
\text { GGATTGAGAGCACGCCTTATTATTATCTCTTGGCGTGCAGTGGTAGA } \\
\text { GCAGTTGTTCTCAATCCCTATCTCCA ACAACTGCTCTA }\end{array}$ \\
\hline & $\mathrm{D}$ & $\begin{array}{l}\text { TAGAGCAGTTGTTGGAGATAGGGATTGAGAACAACTGCTCTACCACT } \\
\text { TTTCTCAАTCCСТАTCTCCA ACAАCTCGACACССАCT }\end{array}$ \\
\hline & Rep-B & TAGGAGTCGCCAAGAGATAATAATAAGGCG \\
\hline & Rep-C & CGCCTTATTATTATCTCTTGGCGACTCCTA \\
\hline & Act-B & GCGGAATAATAATAGAGAACCGCTAGGACT \\
\hline & Act-C & AGTCCTAGCGGTTCTCTATTATTATTCCGC \\
\hline \multirow{9}{*}{$\begin{array}{l}\text { Assembly of } \\
\text { 3-arm DNA } \\
\text { structures on } \\
\text { cell surface }\end{array}$} & A & GTCTGTGATAGGGAGAGTTTACTCACAACACTCTCCCT-6-FAM \\
\hline & $\mathrm{B}$ & $\begin{array}{l}\text { AGGGAGAGTCGTGCGGTTCTCTATTATTATTCCGCACGGTTGTGAGT } \\
\text { TTATCACAGACACTCACAA/iBHQ2dT/TTTTTTT-Chol }\end{array}$ \\
\hline & $\mathrm{C}$ & $\begin{array}{l}\text { Dabcyl- } \\
\text { AGGGAGAGTGCACGCCTTATTATTATCTCTTGGCGTGCGTTGTGAGT } \\
\text { TTATCACAGACACTCACAATTTTTTTT-Chol }\end{array}$ \\
\hline & $\mathrm{D}$ & Cy5-TTGTGAGTGTCTGTGATTTACTCTCCCTATCACAGAC \\
\hline & I & ACTCACAACACTCTCCCT \\
\hline & Rep-B & GCGGAATAATAATAGAGAA CCGCTAGGACT \\
\hline & Rep-C & TAGGAGTCGCC AAGAGATAATAATAA GGCG \\
\hline & Act-B & AGTCCTAGCGG TTCTCTATTATTATT CCGC \\
\hline & Act-C & CGCCTTATTATTATCTCTT GGCGACTCCTA \\
\hline \multirow{5}{*}{ Cell assembly } & Chol-A & $\begin{array}{l}\text { GTCTGTGATCGTGCGGTTCTCTATTATTATTCCGCACGAGGGAGAGT } \\
\text { ACTCACAACACTCTCCCTTTTTTTTT-Chol }\end{array}$ \\
\hline & Chol-B & $\begin{array}{l}\text { CGCAAGGCGGCGTGCGAAAACCAGCAACGACCGCACGCGGTGGGAC } \\
\text { GCGCCTTCTCCGATGCAACTTTTTTTT-Chol }\end{array}$ \\
\hline & Chol-C & $\begin{array}{l}\text { Cy5- } \\
\text { AGGGAGAGTGTTGTGAGTATCACAGACACTCACAATTTTTTTTTTTTT } \\
\text { TTTTTTT-Chol }\end{array}$ \\
\hline & $\mathrm{D}$ & TTGTGAGTGTCTGTGATTTACTCTCCCTTTATCACAGAC \\
\hline & Chol-E & 6-FAM- \\
\hline
\end{tabular}




\begin{tabular}{|c|c|}
\hline & $\begin{array}{l}\text { GTTGCATCGGAGAAGGCGGCTCGGTATGGTTGGCGTTTTTTTTTTTTT } \\
\text { TTTTTTT-Chol }\end{array}$ \\
\hline $\mathrm{F}$ & CGCCAACCATACCGAGCTTCGTCCCACCTTCGCCTTGCG \\
\hline $\mathrm{I}_{1}$ & ACTCTCССТTTATCACAGAC \\
\hline $\mathrm{I}_{2}$ & CGTCCCACCTTCGCCTTGCG \\
\hline Rep-A & GCGG AATAATAATAGAGAA CCGCTAGGACT \\
\hline Rep-B & TAGGAGTCGCC AAGAGATAATAATAA GGCG \\
\hline Act-A & AGTCCTAGCGGTTCTCTATTATTATTCCGC \\
\hline $\begin{array}{l}\text { Mock- } \\
\text { Act-A }\end{array}$ & GCTGCTTCCGCAGGTCATGGCAACATGCCG \\
\hline Act-B & CGCC TTATTATTATCTCTT GGCGACTCCTA \\
\hline $\begin{array}{l}\text { Mock- } \\
\text { Act-B }\end{array}$ & GCAAGCTATACCAAGCGTTCCGGTGGGCAT \\
\hline
\end{tabular}

